This is a pre-proof version of an article in:

Arnaud, E. and Martini, I. P. 2009. Glaciations- Pre-Quaternary. In Gornitz, V. (ed)

Encyclopedia of Paleoclimatology and Ancient Environments. Encyclopedia of Earth Sciences Series, Dordrecht, Netherlands: Springer, 384-389.

The definitive version is available at www.springer.com 


\section{GLACIATIONS, PRE-QUATERNARY}

\section{Introduction}

Earth has experienced recurring periods of glaciation (icehouse climatic conditions) alternating with periods of warm climate (greenhouse climatic conditions) (Fig. 1; Hambrey and Harland, 1981; Eyles, 1993; Crowell, 1999). Except for the Mesoproterozoic (c. 2-1 Ga) in Precambrian times and the Mesozoic (250-65 Ma) in Phanerozoic times, glaciations occurred on one continent or another (Fig. 2 ).

Insolation, agglomeration, splitting and drifting of continents and related orogenies are the first-order controls for changing climatic conditions on Earth. Some glacial periods correlate reasonably well with major orogenic phases (Fig. 1); that is, with the agglomeration of continents and the change in distribution and volume of oceanic basins. The relative position and elevations of continents affected oceanic and atmospheric circulation and the associated redistribution of heat, as well as the degree of weathering of exposed rock and the associated sequestration of atmospheric $\mathrm{CO}_{2}$. These factors contributed to the development of icehouse and greenhouse conditions and to glaciations. Other factors such as orbital parameters further modulated the behaviour of glaciers during icehouse periods.
Recognition of ancient glaciations is based on type and distribution of sedimentary deposits, fossil assemblages and their isotopic composition, and, in some cases, on erosional features. However, the older the glaciation, the less reliable and abundant the information is. Ancient glacial deposits may have been deeply buried, modified by metamorphism or selectively preserved in basins not subsequently affected by erosion. In addition, it is more difficult both to interpret the paleoenvironment of older deposits as different processes may have formed similar features, and also to date them because fossils or other suitable dateable material may be absent, and chemical (isotopic) composition of waters and atmosphere may have been different.

The following are the most common, effective lines of evidence used to establish the occurrence of an ancient glaciation. No single indicator, however, provides unequivocal proof of glaciation; it is the assemblage of several criteria, abundantly present in an area, which can be used to infer cold climate and presence of glaciers.

\section{Depositional Features}

The presence of widespread, thick when marine, diamictite associated with cold-climate indicators is the 


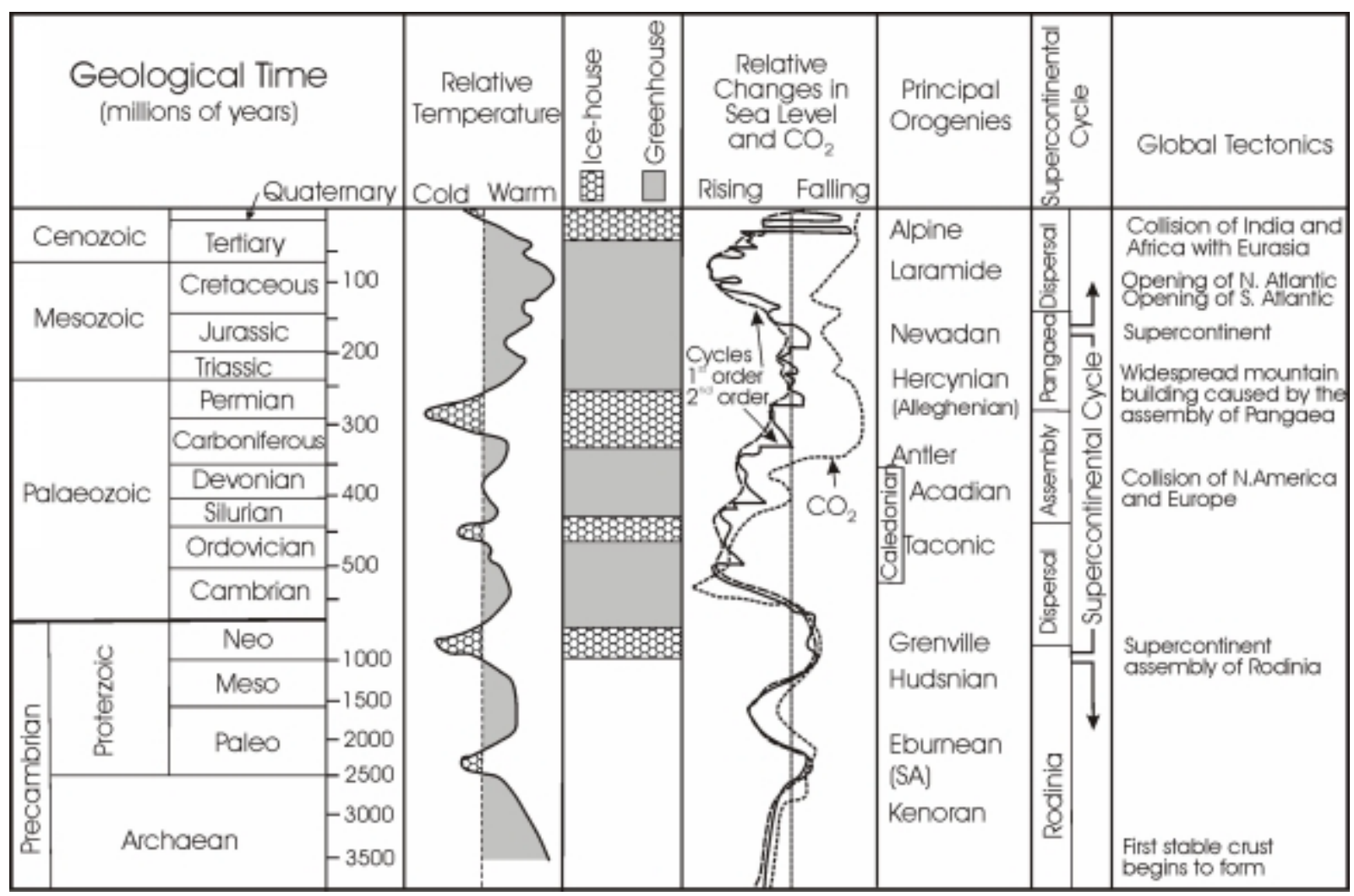

Figure 1 Major tectonic, environmental and climatic change on Earth (after Doyle et al., 1995; with data from Berner, 1990;

Young, 1999; Young, pers.comm. 2003).

most frequently used criterion to establish glacial conditions. Diamictite is a rock derived from diamicton -- a poorly sorted mixture of mud, sand and gravel (Fig. 3). Diamicton may be deposited directly by glaciers (till; tillite when cemented), or formed by other sedimentary processes, such as rainout of finegrained suspended sediment and ice rafted debris, and debris flow in terrestrial or subaqueous conditions. The presence of extensive diamictite that contains faceted clasts is a strong initial clue of glaciation when tectonic influences (such as non-glacial debris flow caused by tectonic activity) can be confidently discarded. However, it is difficult to determine whether diamictite is of glacial or non-glacial origin. It is therefore critical to look at the characteristics and distribution of associated deposits in order to establish the paleoclimatic significance of diamictite. When abundant, shape and surface texture of clasts, from bullet-shaped, faceted, and striated pebbles and boulders, to imprints and chattermarks on sand grains, are powerful 

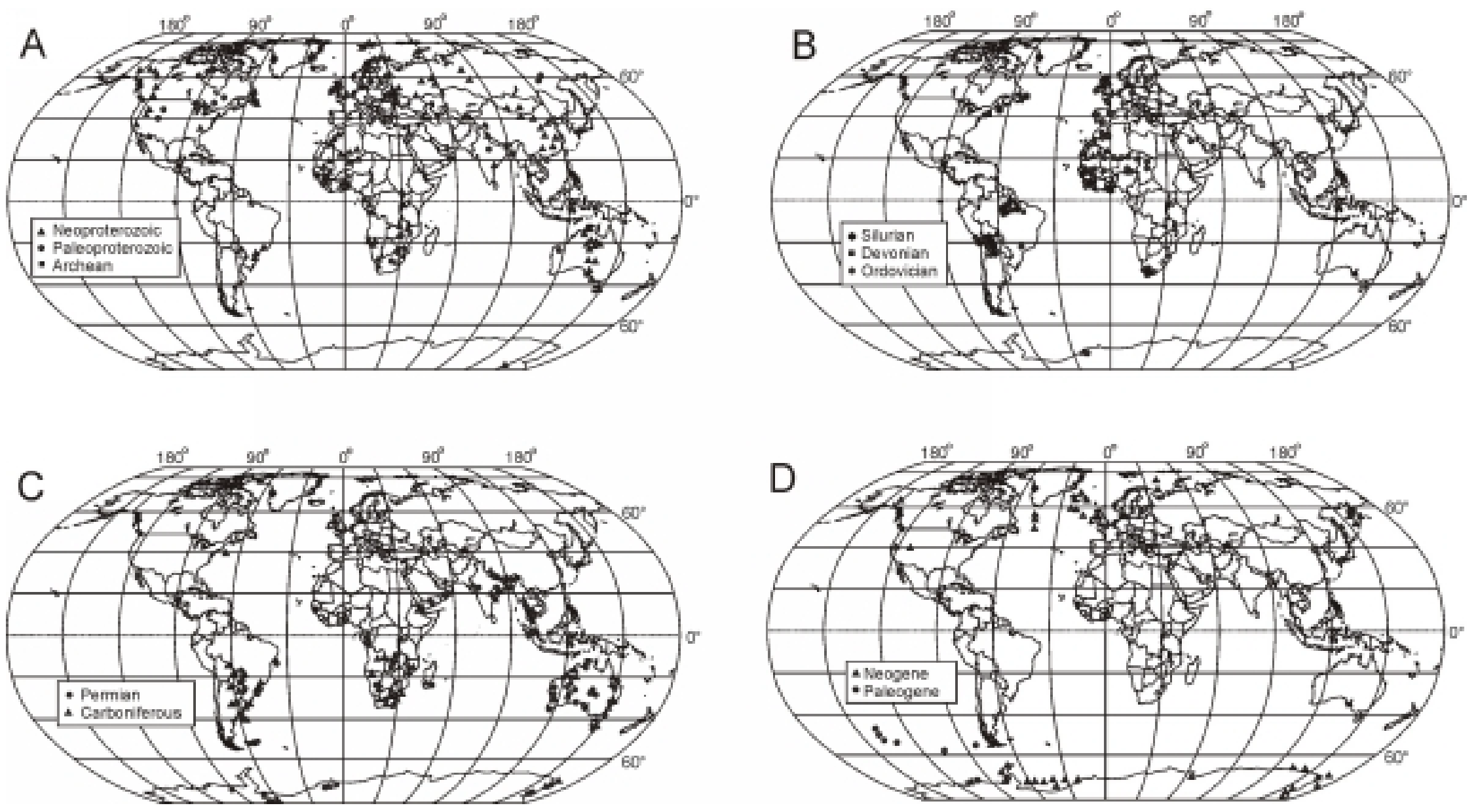

Figure 2 Maps of locations showing the recorded glacial features on Earth: A. Precambrian; B. Early Paleozoic; C. Late Paleozoic; D. Cenozoic (after Hambrey and Harland, 1981; Martini et al., 2001; and some data from Evans, 2000) 
indicators of glacial action. However, these may not indicate direct deposition by ice as clasts may be reworked under other depositional conditions. Although boulder pavements are commonly used as glacial indicators in the Quaternary, they are rarely identified in more ancient examples. Presence of dropstones (lonestones) and deposits with textural inversions (such as randomly distributed lenses or pockets of sand and/or coarser-grained material in finegrained deposits) are interpreted to indicate ice rafting and dumping from iceberg and seasonal ice floes, although they need to be distinguished from material rafted by floating organic debris (algae, trees) in the Phanerozoic. Presence of sand, silt, and clay rhythmites in lacustrine and marine deposits may contribute to a glacial interpretation, although they may also be formed by turbidity currents not necessarily derived from glaciers. True varves, the typical clay-silt or siltsand couplets formed annually in ice-covered lakes, are rarely identified in pre-Quaternary successions because it is usually impossible to confirm that each couplet represents a year of deposition. Of interest is the fact that loess, so common in Pleistocene periglacial settings, is not reported from pre-Quaternary glacial deposits. This may be a matter of poor preservation of exposed terrestrial material; its ancient equivalent would likely be subaqueous silty deposits. Depositional landforms such as drumlin and eskers have rarely been used to establish glaciation, one of the debatable exceptions being for the Carboniferous in Brazil.

\section{Biological and Geochemical Features}

Cold climate flora (mainly terrestrial) and fauna (terrestrial and marine) and their related deposits, such as coal and ooze, are strong indicators of cold settings during Phanerozoic times. Isotope (such as O, C) analyses of skeletal marine microfossils can also provide indication on the presence and amount of glacial ice.

\section{Erosional/Deformation Features}

Abraded pavements on bedrock are often found with striations, and some chatter marks, crescent gouges, and lunate fractures. Striated pavements are common throughout the ages (Laajoki, 2002). They can be formed by glaciers, but also by other unrelated tectonic (slickensides) and depositional (debris flows) processes. Large-scale erosional features such as roche moutonnées, crag and tails, and rock channels have rarely been used to establish glaciation, except in exhumed Ordovician surfaces in NW Africa. When extensive, furrows in marine and lacustrine deposits are occasionally taken to indicate scouring by icebergs or seasonal ice floes (such as for the Ordovician in Brazil). Associated with other cold 


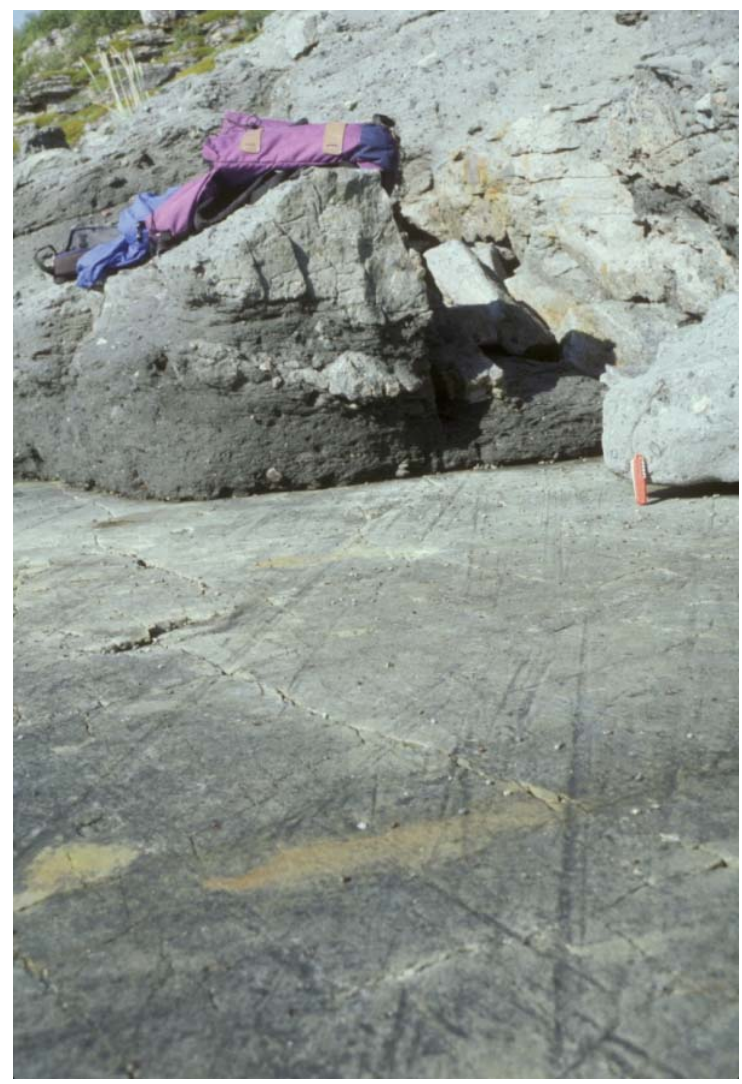

Figure 3 Neoproterozoic diamictite of the Smalfjord Formation overlying a striated pavement, Bigganjargga, northern Norway.

climate evidence, sandstone wedges have also been used to indicate frozen ground conditions.

\section{Precambrian glaciations}

Archean

Archean-age glacial deposits (2990-2870 Ma) have been reported from South Africa. Diamictites are observed with occasional striated and faceted clasts at three different stratigraphic levels within the
Witwatersrand Basin, both in outcrops and subsurface mining walls. Diamictite up to $80 \mathrm{~m}$ thick containing glacially striated and faceted clasts have also been found in the Pongola Basin. Other diamictites have been observed in northern Europe and North America but their glacial origin is debated.

\section{Paleoproterozoic}

Glacigenic deposits of Paleoproterozoic age have been documented in North America (Huronian), South Africa (Makganyene), Finland-Russia (Karelian) and western Australia (Hammersley). Good exposures of Paleoproterozoic glacial deposits occur within the Huronian Supergroup in Ontario, Canada. The Gowganda Formation consists of diamictites with some faceted clasts overlying striated pavements, and thinly laminated argillite with abundant dropstones. These diamictites have accumulated in a predominantly glaciomarine setting. The laminated argillites were thought to be varves formed in a glacially influenced, subaqueous setting, but this cannot be confirmed in the absence of high resolution (annual) dating of these deposits.

The age of the Gowganda Formation has been bracketed between 2670 and 2220 Ma by underlying volcanic rock and a crosscutting diabase. The age of other Paleoproterozoic glacigenic successions are equally poorly constrained and ranges between 2050 
and 2700 Ma. While the deposits in South Africa, Finland-Russia and western Australia are thought to be broadly correlative with the North American Huronian glacial deposits, their synchronous deposition is speculative.

\section{Neoproterozoic}

The striated pavement and overlying diamictite exposed on the shores of Varangerfjorden, Norway (Fig. 3) were first described in 1891 and used to infer a Precambrian-age glaciation. This was one of the first Neoproterozoic glacial deposits to be described; others have since been documented from every continent (Crowell, 1999). Evidence for glacial conditions includes striated pavements, striated and faceted clasts, marine diamictite and laminated mudstone with dropstones.

Two major glacial periods have been established in the Neoproterozoic, with growing evidence for a third. Glacial deposits are commonly ascribed to either of the two glacial periods based on lithological characteristics, biostratigraphy (acritarchs and Ediacaran fauna), chemostratigraphy $\left({ }^{* 13} \mathrm{C}\right)$ of associated carbonates and radiometric dates (Hambrey and Harland, 1985; Knoll, 2000). The oldest glaciation (c. $725 \mathrm{Ma}$ ) is commonly referred to as Sturtian, whereas the youngest (c. $600 \mathrm{Ma}$ ) has been referred to as Marinoan (Australia, Canada) or Varangian (North
Atlantic). However, there is still much debate about the age and stratigraphic correlation of these glacial deposits and the number and extent of Neoproterozoic glaciations (Knoll, 2000).

Various aspects of the Neoproterozoic geologic record suggest that glaciations of this time may have been more severe than those of the Phanerozoic. The widespread distribution of diamictites including some at low paleolatitude has been used to infer that ice possibly covered the entire world (Harland, 1964). Inferred glacigenic deposits are commonly associated with carbonates that exhibit strong fluctuations in ${ }^{* 13} \mathrm{C}$. The close juxtaposition of glacigenic deposits and presumably warm water carbonates has been used to suggest relatively rapid climate change between glacial and warm conditions, whereas the ${ }^{* 13} \mathrm{C}$ fluctuations imply significant perturbations in seawater geochemistry (Harland, 1964; Hoffman et al., 1998). The low latitude (equatorial) deposition of some glacial deposits has been suggested by paleomagnetic analyses, although it has only been confidently demonstrated for the Elatina Formation in Australia (Evans, 2000). Nevertheless, several scenarios have been proposed to explain low latitude glaciations, including a 'snowball' Earth encased in ice as a result of increased reflectivity or 'runaway albedo', glaciations during a significant change in tilting of the Earth's rotating axis, and high-mountain 
glaciers associated with tectonic uplift. Further research on Neoproterozoic successions and a more robust geochronological framework are needed to fully evaluate the plausibility of these scenarios.

\section{Phanerozoic glaciations}

In contrast to the Quaternary of the Northern Hemisphere, mid-latitude glaciations are uncommon throughout the rest of the Phanerozoic: extensive glaciers occupied high-latitude landmasses during the Permian-Carboniferous and Ordovician, and localized glaciations occurred during other periods. No glaciations have been recorded during the Mesozoic, although the presence of ice at the poles has been suggested by local occurrence of rafted debris.

\section{Paleozoic glaciations}

The Paleozoic is characterized by three periods of icehouse conditions centered over North Africa and South America (Ordovician), South America (Devonian), and Australia, Africa, South America, India and the Arabian Peninsula (Carboniferous) (Fig. 2). This reflects, for the most part, polar wondering and drifting of the continents into and away from mid-high latitudes where glaciers could develop (Caputo and Crowell, 1985).

The Ordovician glaciation (c. $440 \mathrm{Ma}$ ) was the first major Phanerozoic glaciation; it was centered in northwestern Africa (Ghienne, 2003). The evidence consists of a widespread exhumed surface with striated pavements, polished surfaces and other erosional features, and well-developed diamictites (presumably tillites). Glaciomarine deposits of equivalent age are reported from farther south, in Sierra Leone. One apparent anomaly is that the Ordovician glaciations occurred when the tropical water temperature was just $30^{\circ} \mathrm{C}$ cooler and the $\mathrm{CO}_{2}$ partial pressure was about 15 times higher than the Present (Fig. 1). This suggests that cooler conditions are not always related to low concentrations of $\mathrm{CO}_{2}$ in the atmosphere. Perhaps the continents being located near the poles offset these apparently adverse conditions for glaciations to occur.

The Ordovician glaciations had a worldwide effect on relative sea-level change. It contributed to the interruption of the major, early Phanerozoic transgression, forcing a regression from the end of the Ordovician to the start of the Silurian. The postglacial transgression led to the re-establishment of normal fauna, extensive development of reefs and of several, early Silurian euxinic basins. This cycle is recognized in various places such as South Africa, Turkey, South America, Europe, and North America where either thin diamictites and/or significant unconformities mark or occur stratigraphically close to the Ordovician-Silurian boundary. 
Though not yet well studied, early Silurian deposits of possible glacial origin have been reported from southwestern South America (Argentina, Brazil, Bolivia).

The Devonian glaciation was mostly limited to South America (Caputo and Crowell, 1985). The evidence consists mainly of widespread, thick (up to 600 m) marine diamictite whose origin has been indirectly related to regional glaciations.

During the Late Carboniferous - Early Permian ( 350-250 Ma), Earth experienced some of the most widespread and longest glaciations recorded during the Phanerozoic. These glaciations affected the southernmost part of Pangea with terrestrial (tillites?) and widespread marine diamictites occurring primarily in Australia, South Africa, South America and southern Asia. The growing and waning Ordovician glaciers also had significant impact on distant northern lands, where thick, coal-bearing deposits show cyclicity (cyclothems) that ultimately record relative sea-level changes. For the first time in Earth's history, cold climate conditions are also indicated by terrestrial plants and coal deposits (Fig. 4). Although these ancient plant assemblages were very different from the present ones, they occupied analogous environments and produced similar products (peat; coal upon diagenesis). In most cases, the Permian-
Carboniferous diamictites are overlain by marine deposits, and these in turn by continental deposits, some bearing coal derived from warm-climate peat. In other instances though, glacial deposits are interlayered with and overlain by coal-bearing units, where the cold climate origin of the coal can be established though pollen and plant macrofauna analysis. A good record of climatic changes from Upper Carboniferous-lowermost Permian glacial cold conditions, to middle-upper Permian-Triassic warm settings has been established in South Africa (Fig. 4; Falcon, 1989).

\section{Cenozoic glaciations}

The Tertiary (65 to $2 \mathrm{Ma}$ ) and Quaternary (2 Ma to Present) periods constitute the Cenozoic Era. Here we deal with the deteriorating Tertiary climate and possible glaciations that developed at high latitudes. The warm climate conditions persisted throughout the globe during the early Tertiary with its warmest time about $50 \mathrm{Ma}$ (Eocene); this is indicated by vertebrate fossils such as alligators in Arctic islands and tropical marine microfossils (foraminifera and coccoliths) in North Atlantic deposits. Climatic deterioration occurred from 40 to 25 Ma (late Eocene and Oligocene) leading to the colder conditions of the late 


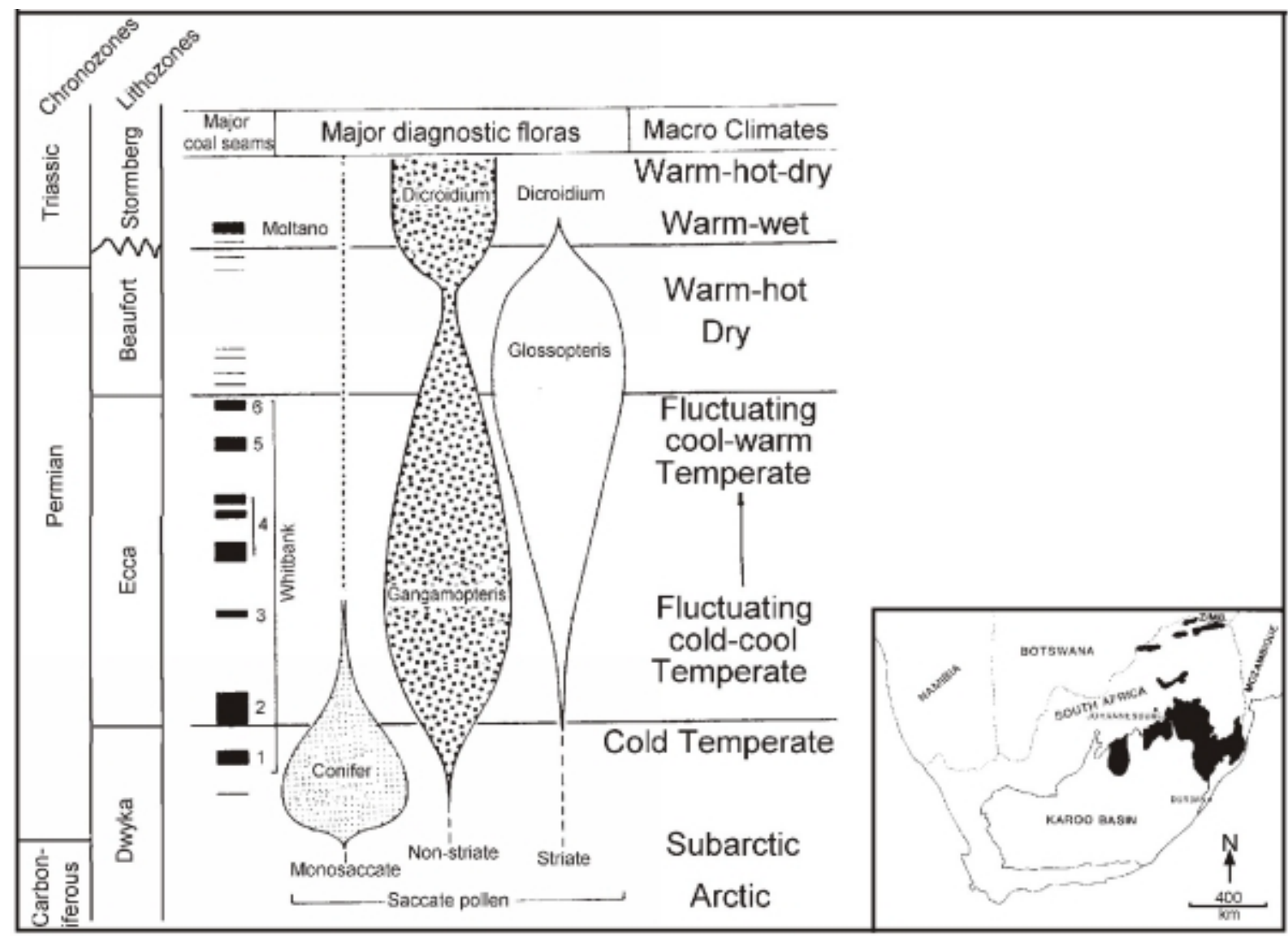

Figure 4 Schematic diagram showing the stratigraphy, major coal seams, diagnostic floras and inferred macroclimates for the Upper Carboniferous to Triassic succession in South Africa. The succession records the following changes in depositional environment: glacially-influenced marine conditions (Dwyka Group), deep to shallow marine environments (Ecca Group) and fluvial environments (Beaufort and Stormberg groups). Note the change in diagnostic flora from the glacial conditions of the Late Carboniferous-early Permian to the temperate-cold middle Permian, and to the warm late Permian-Triassic (from Martini et al., 2001; after Falcon, 1989)

Cenozoic Era. Ice rafted material and ${ }^{* 18} \mathrm{O}$ of marine microfossils indicate that Antarctic polar sea ice and continental glaciations may have developed by about 3634 Ma (early Oligocene). The Antarctic glaciations expanded considerably between 15-10 Ma (Miocene). Associated large, sea-level changes dramatically influenced distant areas. For example, the connection between the Mediterranean Sea and the Atlantic Ocean was cut off at this time, leading to widespread deposition of evaporites and what is commonly referred to as the Mediterranean salinity crisis. The onset of glaciations in the Northern Hemisphere dates from about $6 \mathrm{Ma}$ and the mid-latitude continental ice sheets started developing 
approximately 3 Ma (Pliocene). This is indicated by variations in marine microfossil fauna and abundance of ice-rafted material in northern seas.

\section{Conclusion}

Glaciations have existed on various continents throughout Earth history, although some local records are still debated. Many hypotheses have been put forward to explain the distribution of glacial periods in time and space, none of which are all encompassing. Every major glaciation has its own peculiarities, but all appear to require a cool atmosphere, the presence of continents at or near the poles, and some region-wide obstruction that impedes the redistribution of heat across latitudes. An intriguing correlation that has long been noted is the development of icehouse conditions with major orogenies, which change the physiography of significant part of the Earth's surface and may indirectly affect the composition of the atmosphere. In addition, the two longest cold periods (Neoproterozoic and Permian-Carboniferous) coincide with periods of time where global tectonics are characterized by supercontinents. Recent developments in various fields of geology (such as isotope geochemistry and geochronology) provide promising avenues of research in pre-Quaternary glacial geology.

Emmanuelle Arnaud and I. Peter Martini

\section{Bibliography}

Berner, R.A., 1990. Atmospheric carbon dioxide over Phanerozoic.time. Science, 249: 1382-1386.

Caputo, M.V. and Crowell, J.C., 1985. Migration of glacial center across Gondwana during the Paleozoic Era. Geological Society of America Bulletin, 96: 1020-1036.

Crowell, J.C., 1999. Pre-Mesozoic ice ages: their bearing on understanding the climate system, 192. Geological Society of America, Memoir, 106 pp.

Doyle, P., Matthew, R.B. and Baxter, A.N., 1995. The key to Earth history: an introduction to stratigraphy. J. Wiley \& Sons, New York, $231 \mathrm{pp}$.

Evans, D.A.D., 2000. Stratigraphic, geochronological, and paleomagnetic constraints upon the Neoproterozoic climatic paradox. American Journal of Science, 300: 347-433.

Eyles, N., 1993. Earth's glacial record and its tectonic setting. Earth Science Reviews, 35: 1-248.

Falcon, R.M.S., 1989. Macro- and micro-factors affecting coal seam quality and distribution in southern Africa with particular reference to the No. 2 Seam, Witbank coalfield, South Africa. International Journal of Coal Geology, 12: 681-731.

Ghienne, J.F., 2003. Late Ordovician sedimentary environments, glacial cycles and post glacial transgression in the Taoudeni Basin, West Africa. Palaeogeography, Palaeoclimatology, Palaeoecology, 189: $117-145$

Hambrey, M.J. and Harland, W.B. (Editors), 1981. Earth's prePleistocene glacial record. Cambridge Earth Science series. Cambridge University Press, Cambridge, 1004 pp.

Hambrey, M.J. and Harland, W.B., 1985. The late Proterozoic glacial era. Palaeogeography, Palaeoclimatology, Palaeoecology, 51: 255272. 
Harland, W.B., 1964. Critical evidence for a great infra-cambrian glaciation. Geologisches Rundschau, 54: 45-61.

Hoffman, P.F., Kaufman, A.J., Halverson, G.P. and Schrag, D.P., 1998. A Neoproterozoic snowball earth. Science, 281: 1342-1346.

Knoll, A.H., 2000. Learning to tell Neoproterozoic time. Precambrian Research, 100: 3-20.

Laajoki, K., 2002. New evidence of glacial abrasion of the Late Proterozoic unconformity around Varangerfjorden, northern Norway. In: W. Altermann and P. Corcoran (Editors), Precambrian Sedimentary Environments: a modern Approach to ancient depositional systems. Blackwell Science, Oxford, pp. 450.

Martini, I.P., Brookfield, M.E. and Sadura, S., 2001. Principles of glacial geomorphology and geology. Prentice Hall, Upper Saddle River, 381 pp.

Young, G.M., 1999. The Precambrian atmosphere. In: C.P. Marshall and R.W. Fairbridge (Editors), Encyclopedia of Geochemistry. Kluwer Academic Publishers, Dordrecht, pp. 526-532.

\section{Cross references}

Glaciations, Quaternary

“Icehouse” (cold) climates 